This is a pre-publication version of a paper that appears in Development $\mathcal{E}^{2}$ Change

45, 5 (September 2014): http://dx.doi.org/10.1111/dech.12117

Changes are possible; please refer to the version of record. Further information is available at http://kevinpdonovan.com/other-writing

\title{
'Development' as if We Have Never Been Modern: Fragments of a Latourian Development Studies
}

\author{
Kevin P. Donovan
}

\begin{abstract}
The work of the French anthropologist-cum-philosopher Bruno Latour has influenced a wide variety of disciplines in the past three decades. Yet, Latour has had little noticeable effect within development studies, including those subfields where it might be reasonable to expect affinity, such as the anthropology of development. The first half of this article outlines some core aspects of Latour's oeuvre as they relate to development and anthropology, particularly focusing on the post-development critique. Latour's approach to constructivism and translation, his analytical commitment to 'keeping the social flat' and his distribution of agency offer novel ways of maintaining some of the strengths of post-development without falling prey to some of its weaknesses. The second half of this article explores the potential for a Latourinspired theory of development that may provide fruitful avenues for scholarship and practice beyond post-development, emphasizing materialism, relationality and hybridity.
\end{abstract}

This paper began in the Ethnographic Problematiques seminar in UCT's Social Anthropology programme, and I am grateful to the participants for their comments, particularly Francis Nyamnjoh. It also greatly benefited from comments and conversation with Bill Maurer and the astute comments of three anonymous reviewers. It was made possible through financial support as a 2011-12 Fulbright Fellow to South Africa and a fellowship from the Institute for Money, Technology \& Financial Inclusion at UC-Irvine. 


\section{INTRODUGTION}

Actor-network theory (ANT) is a methodology and social theory that was predominantly developed by John Law, Michel Callon, and Bruno Latour, especially through their engagement in studies of scientific practice in the 1970-80s. Its distinctive approach to social science, grounded in materiality, constructivism, and networks of associations, has influenced a wide range of disciplines, yet it has received relatively little attention from development scholars, let alone practitioners. This article considers the relevance of Latour, in particular, for the meeting of anthropology and development. ${ }^{1}$ Latour has used the insights of ANT to ask foundational philosophical questions, especially in his 1991 book We Have Never Been Modern, which made a forceful intervention into debates about modernity (and its variants). ${ }^{2}$

The first half of the article focuses on the 'anthropology of development', in particular the works associated with post-development by Arturo Escobar (1995; 2009), Sachs (1992), Rahnema and Bawtree (1997) and Esteva and Prakash (1998). ${ }^{3}$ Broadly influenced by post-structuralist and Marxist thought, post-development scholars have sought to question and denaturalize the desirability of development through, most notably, historical and contemporary discourse analysis. It has argued that 'development' is a continuation of Western colonialism through, amongst other things, epistemic hegemony, and that instead of alternative development models, what is needed is alternatives to development altogether.

As Ziai (2004: 1054) has delineated, post-development is not monolithic, but rather shorthand for a body of work that includes variants (see also Ahorro, 2008). He divides the scholarship between 'neo-populist' and 'sceptical post-development' depending on how wholeheartedly it embraces traditional cultures (often considered unchanging) and rejects modernity; however, he notes '[i]n almost all post-development texts, one can find these conflicting discourses'. Considered as a spectrum between Ziai's nodes, this article more clearly critiques the neo-populist strains and even finds moments of alignment with elements of the latter, sceptical literature.

The provocative and productive questions posed by post-development raised many unresolved questions, but equally open are some of the tensions within post-development

\footnotetext{
${ }^{1}$ For a recent overview of Latour, see Blok and Jensen (2011) and Harman (2009). Other actornetwork theorists, especially the work on economics of Callon (1998) and Callon et al. (2007), could prove fruitful for development studies as well.

${ }^{2}$ This work was completed prior to the release of Latour's (2013) major new work, An Inquiry into Modes of Existence: An Anthropology of the Moderns, which marks a second phase of his philosophical project.

${ }^{3}$ James Ferguson's (1994) early work was also influential to post-development but has subsequently changed emphases.
} 
which have been the subject of criticism. In a retrospective article, Escobar (2000) noted accusations of over-generalizing, romanticizing local traditions and activism, and ignoring ongoing contestation. Related to these are tendencies to essentialize processes such as 'Development' or 'Capitalism', analyse resistance and development asymmetrically, and fail to account for how resistance is durably overcome.

This article will use actor-network theory's tenets - including its approach to constructivism, flat social analysis and distributed agency - to offer methods through which these criticisms and tensions can be resolved, hopefully building on the provocations and insights of post-development while sharpening and redirecting its approach.

Finally, the second half of the article turns more directly to 'development anthropology', meaning practice-oriented work. It again suggests three conceptual arguments from Latour's work that could provide fruitful avenues for development scholarship and practice 'after post-development' (to borrow from Pieterse, 2000) Specifically, a Latourinspired approach to development would reformulate development anthropology as issueoriented politics, aiming to compose a common world, and attend to development as attachment.

\section{ANT AND THE ANTHROPOLOGY OF DEVELOPMENT}

\section{Translation and the Promises of Constructivism}

Actor-network theory has been described as a 'sociology of associations' (Latour, 2005) that focuses on tracing interactions between entities 'in action' (Latour, 1987a). Instead of accepting social concepts (e.g. 'power') or categories (e.g. 'class') as a priori given, it maintains that these are results, not causes, of associations between heterogeneous actors. This means that actors begin as a fiction, but can become more real through generating interest from others, enrolling them in alliances, and eventually stabilizing enough to be considered - at least for a time - real (Latour, 1996a). Stabilized concepts, categories, and objects are thus the exception, requiring extensive work on the part of actors to construct them. ${ }^{4}$ ANT takes its remit to be tracing the controversies and disputes that must be settled for consensus to be reached.

\footnotetext{
${ }^{4}$ Notably, and controversially, Latour extends this construction to nature, arguing that the Nature/Society (or Object/Subject) divide is merely a convention that presumes an ontological separation that does not exist. Studies of laboratory science led ANT to posit that 'natural facts' are made real only after considerable work has been done in their construction. However, because nonhumans, too, are granted agency (see below), this approach is not to be confused with social constructivism.
} 
The development of stability occurs as entities are enrolled in networks in which they more or less reach agreement. However, because full unanimity is quite rare, Latour emphasizes the concept of 'translation' (from Callon, 1986) that he takes to mean a transformation in goals or meaning that occurs when entities become connected. Action is never accomplished alone, but instead requires networks of collaboration and technological mediation. This delegation means that action is uncertain, in the hands of others, and thus prone to 'a drift, a slippage, a displacement' (Latour, 1999a: 88). This inevitable alteration is what Latour means by translation. In the process of becoming, translation is inevitable, meaning the 'only way to increase a project's reality is to compromise' and thus become more complicated (Latour, 1996a: 99).

Post-development has also taken a constructivist approach, concerned with the historical invention of concepts such as 'progress', 'poverty' or 'development' (see Sachs, 1992; Rahnema and Bawtree, 1997). Much of post-development uses evidence of construction to argue that the resulting fabrications are false..$^{5}$ In some cases, this deceit is taken as cover for the 'true' mission of capitalist imperialism, but the iconoclastic negation in postdevelopment need not always be revelatory. For example, Escobar (1995: 4) documents 'the loss of an illusion, in which many genuinely believed', and Sachs (1992: 1) declares development 'a myth which comforts societies, and a fantasy which unleashes passions'.

But for Latour, despite being a constructivist scholar (2003a), everything a postmoderninspired approach like post-development 'takes to be justification for more absence, more debunking, more negation, more deconstruction, [he takes] as proof of presence, deployment, affirmation, and construction' (Latour, 1999a: 21) That is, constructivism signifies 'an increase in realism' even though, 'unwittingly, constructivism has become a synonym of its opposite number: deconstruction' (Latour, 2005: 92) This commitment to the reality of constructions leads to divergent understandings of agency (discussed below) and offers an alternative to the post-development iconoclasm.

Latour also differs from post-development in a rejection of any universalization. No construction for Latour is ever even close to universal, even within certain populations. In contrast, despite a postmodern effort to reject metanarratives such as progress, one finds totalizing assessments throughout post-development, such as 'the dream [of development] was universally embraced by those in power' (Escobar, 1995: 4), or a characterization of 'almost unanimous support for development' (Rahnema and Bawtree, 1997: ix) Although post-development has made efforts to avoid this tendency - notably through its studies of resistance - it creeps in, fundamentally because the underlying social theory allows it to in a way ANT would not.

\footnotetext{
${ }^{5}$ It should be noted that some associated with post-development explicitly reject this conclusion (e.g. Ferguson, 1994), but they are the exception.
} 
Placing stabilized entities at the end of analysis, not the beginning, tests post-development approaches. Nothing is capable of diffusing outward from a 'core' to the 'periphery' in a pure state, but instead an innovation or project begins as a fiction, neither inherently realistic nor unrealistic, and certainly not possessing any power in its fictive state. In time, it becomes 'more real or less real, depending on the continuous chains of translation' that it enrols through generating interest (Latour, 1996a). ${ }^{6}$ The only way for a project to create these chains, though, is to compromise, thus becoming more complicated as more interests are enrolled. Maintaining meaning and goals - whether it is a public transport system in Paris (Latour, 1996a) or a rural development programme in India (Mosse, 2005) - is a constant struggle.

Putting translation at the core of an analysis, as Latour does, shifts attention away from the dominant post-development narrative of 'capitalism' or 'Westernization' diffusing outward from the core. For some post-development authors, 'local resistance' is the means through which the domineering entity can be altered or stopped - though, more likely, the overwhelming power of development will render the resistance impotent (Escobar, 1995: 155). The inclusion of resistance in their analysis is explicitly taken as evidence that post-development avoids the unidirectionality and intentionality to which discourse analysis often falls prey (e.g. Escobar, 1995: 11). But instead of starting with these forms of hybridity and the translation of 'development' that they necessarily entail, post-development starts with essentialized concepts and has to note the diversity in passing.

For example, Escobar (1995: 50) cites a small village in Papua New Guinea where 'traditional' festivals incorporate 'modern' Western goods like Nescafé, and notes that 'they have developed a hybrid model of sorts' and that 'the concepts of development and modernity are resisted, hybridized with local forms, transformed, or what have you'. The conflation of adopting consumer goods with 'resistance' is indicative of the general approach to 'locals' in post-development. The tendency to dichotomize the world (discussed at length below) results in an overly simplistic subject/object relationship between 'development' and 'locals' who, if they are to become the topic of discussion, are typically engaged in resisting the top-down application of development. Thus, villagers drinking Nescafé become la résistance, and any 'local' supporters of development initiatives tend to be operating under false consciousness (Escobar, 1995: 52, 147).7

\footnotetext{
${ }^{6}$ For a discussion of ANT with regard to (critical) realism, see Elder-Vass (2008).

${ }^{7}$ In contrast, Mosse (2005: 6) presents an anthropology of development that 'is distinctly uncomfortable with monolithic notions of dominance, resistance, hegemonic relations and the implications of false consciousness among the developed (or the developers)'. Also see Lewis and Mosse (2006).
} 
Left largely unexplored is the alternative hypothesis that those 'locals' - whether bureaucrats or peasants - that support and enable a development project do so by choice. ${ }^{8}$ An ANT approach to development would be concerned with tracing the activity by which locals become included in an intervention, trusting in their agency and right to be convinced that becoming enrolled in 'development' is in their interest. ${ }^{9}$ Although in some moments post-development work has a more dynamic view of 'traditional' culture, in cases throughout core texts like Rahnema and Bawtree (1997) one finds a static conception of culture to be defended from change (see Ziai, 2004).

In a way, actor-network theory offers a more radical, and certainly more differentiated, account of 'development' processes. Instead of resistance being the primary source of change for entities taken to have an essence, ANT foregrounds the myriad alterations, as well as documents the rare cases in which enough work has been done to allow something to be transmitted without transformation. It therefore foregrounds issues of failure within development. In this account, even active supporters, let alone resistors, serve to transform projects that began as fictions. Where post-development begins with homogeneous entities that may or may not become hybridized, ANT attends to the inherent diversification as networks of association lengthen, incorporating more actors. Put simply, 'to adopt is to adapt' (Akrich et al., 2002), whether one is a World Bank functionary or an altermondialiste activist. In this way, post-development's search for 'alternatives to development' is implicated because development can no longer be considered unitary.

The centrality of 'locals' in post-development also has another effect. In postdevelopment, constructivism tends to be asymmetric: locals are portrayed as active network builders whose efforts to form resistance and alternative modernities are richly portrayed as costly and time-consuming, while the work of development comes off as effortless diffusion from the core (cf. Ferguson, 1994: 224-25). ${ }^{10}$

Take, for example, Escobar's (2009) ambitious study of activism in the Colombian Pacific region after it was invented as a 'developmentalizable' entity. The activist-intellectuals who he studied for years are excellently documented in their network building and

\footnotetext{
${ }^{8}$ It would be a mistake to ignore the limited options available to many communities postdevelopment studies, risking the criticism that ANT is biased towards 'winners' to the detriment of those who are excluded or harmed by the stabilization of networks (on this, see Haraway, 1994; Star, 1991;)

${ }^{9}$ What Akrich et al. (2002) call interessement - the active adoption of change through an innovation by parties that have become interested in it - is core to their theory of how innovations spread and change occurs. It follows from their repudiation of fixity and closure. ${ }^{10}$ To be clear, the focus on local populations has rich benefits, as well, not the least of which is documenting development's destructive possibilities, as well as emphasizing the diversity of knowledge production.
} 
advocacy efforts across the globe. As he writes, 'What made the black community thinkable and material is precisely the dense interweaving of expert, state, place-based and activist techniques with their corresponding mediations. The result has been a significant reconfiguration of modalities of power' (ibid.: 161).

In contrast, the deployment of capitalist development networks - with all the concurrent translations involved - is largely ignored. ${ }^{11}$ As one reviewer (Hale, 2009: 828) wrote, a reader does catch glimpses of local support for 'development', such as 'individual proprietor shrimp farming and agricultural cooperatives that produce for the market', or groups other than the activists 'who have very different development aspirations', but these are largely bracketed. The result is an asymmetric explanation, where preordained 'power' explains 'development' while costly and difficult network building explains resistance. Adapting Latour (2004: 35), we might say, each time one risks falling into fascination with development's power, one has only, in order to sober up, to add up the networks that allow it to spread faithfully and combine with other entities to make action at a distance possible. While post-development does this in some cases, in others it falls back upon the structuralism that is the focus on the next section.

\section{Keeping the Social Flat}

Admittedly, the activists, not the developers, were the focus of Escobar's study, but the largely unquestioned essentialization and unification of those critiqued by postdevelopment - development, capitalism, empire, etc. - results in a weaker understanding of how those actually come to be and function. Further, this way of thinking about capitalism 'has made it so difficult for people to imagine its supersession' (Gibson-Graham, 1996: 4), and relegates economic difference and plurality to positions of subordination and shortcoming. In their acceptance of sui generis entities called 'capitalism' or 'development', many post-development authors are too quick to establish binaries, such as global versus local. The tension is emblematic of the wider structure/agency paradox (Bourdieu, 1977; Merton, 1968) in social science for which ANT has proposed a novel analytical solution: keeping the social flat.

As with his rejection of a priori given social concepts like 'power' or 'class' as explanations instead of results, Latour argues against unquestioned assumptions of structure and agency. Instead, he emphasizes the importance of a 'flat' approach to social analysis. Consider the global/local dichotomy that posits local communities exist within or below

\footnotetext{
${ }^{11}$ For Latour, actor-networks are the ontological basis of reality, meaning that something only becomes real through the enrollment of supporting actors in a network. It should be clear that Latour's definition of network is completely distinct from the common technical meaning (e.g. sewage or electrical network) or the organizational meaning (versus hierarchies or markets) (2005: 129) Thus, something that does not have the topology of a network can still be analyzed through an actor-network approach.
} 
global processes. For Latour (2005: 179), 'There exists no place that can be said to be "non-local", so the study of supposedly global entities must be done locally. Influenced by the ethnomethodology of Garfinkel (1967), ANT is focused on locating the places where the so-called macro takes place: 'No place can be said to be bigger than any other place, but some can be said to benefit from far safer connections with many more places than others' (Latour, 2005: 176) Therefore, instead of attributing causation to a 'spirit' of capitalism or any other macro actor, Latour says to look at, say, a Wall Street trading room and the way it is networked to many other places. 'Scale', he says, 'is the actor's own achievement' (ibid.: 185) and the task of the analyst is to understand how it is achieved in practice. This is 'flat' social analysis because actors and analytic categories (e.g. class or nation states) are not positioned above or below others.

This process of 'localizing the global' should be complemented by 'globalizing the local'. The common criticism that micro-level analysis doesn't capture all that is influencing a local experience is correct, but those distant forces are not 'oozing out of a global context, of an overarching framework, of a deep structure' (ibid.: 193) Instead, 'what has been designated by the term 'local interaction' is the assemblage of all the other local interactions distributed elsewhere in time and space, which have been brought to bear on the scene through the relays of various non-human actors' (ibid.: 194) Thus, it is through black boxes, standards, measurements, infrastructure and other inanimate objects that 'the global' is animated in particular times and places. ${ }^{12}$ Scott's (1999) study stands out as an excellent example of how 'capitalism' or 'the state' becomes localized through concrete survey practices, classification techniques, and standardizations; similarly, Mitchell (2009) shows the role of technique in his study of oil and democracy. An ANT approach to development would similarly give attention to how globally dispersed norms and practices come to a local development initiative (additionally, see Law, 2004)

The structure/agency tension for which Latour offers 'keeping the social flat' as a solution is a matter of inquiry in some of the more careful post-development scholarship. For example, Ferguson (1999: 97-109, 221-28) uses a micro-level approach to both provide insight into urban Zambia and to question the continued productivity of place-based ethnography when a bounded and knowable ethnos is clearly absent. ${ }^{13}$ Ferguson's concern with the limitations of 'local' as an analytical concept, though, does not extend equally to

\footnotetext{
12 'Black boxing' refers to the fact that the more successful an innovation becomes, the more opaque it is: 'When a machine runs efficiently, when a matter of fact is settled, one need focus only on its inputs and outputs and not on its internal complexity' (Latour, 1999a: 304).

${ }^{13}$ Additional work (Gupta and Ferguson 1997) expands this inquiry into the meaning of space in anthropology. Similarly, Latour (1991a: 116) has asked, 'Is anthropology forever condemned to be reduced to territories, unable to follow networks?'
} 
'global'. ${ }^{14} \mathrm{He}$ argues that the performative, interactionist analysis must be complemented by 'historical structures and political-economic determinations' (Ferguson, 1999: 98). The risk of this is what Mosse (2005: 6), following Latour, calls a 'new functionalist' sociology that may subsume agency into structure.

An actor-network theory approach to development does not mean ignoring differences in capacity to act at scale, as it is often accused (Latour, 1996c). Instead, it foregrounds the ways in which any given actor achieves a difference in relative size by enlisting more entities into their alliance and ensuring their reliable transmission of action (Law, 1986). This requires constant work because society does not have inertia, it must be continually performed and recreated (Latour, 2008). As argued below, if power relationships are more than short-lived, transient interactions - as the post-developmentalists claim they are - then they must occur through 'entities that don't sleep and associations that don't break down' (Latour, 2005). ${ }^{15}$ The benefit of an ANT approach is that by refusing to presume a priori that some actors are more macro than others, it reveals how 'a difference in relative size is obtained' (Callon and Latour, 1981), something particularly apt in situations of social change like those studied by the anthropology of development.

Mosse (2005: 18) provides an astute example of the importance of constant effort in development work through his consideration of how a development project fails because it is unsuccessful in enrolling others in its 'interpretive community'. Practitioners must convince policymakers of their work through alliance building and shaping, leading him to conclude that policy actually follows practice. One might readily imagine a complementary analysis of Zambia where the structural explanation for the 'abjection' portrayed so well by Ferguson (1999) is not explained by invoking pre-existing concepts like 'capitalism', but instead is traced through an analysis of how wider networks - of copper traders situated in London, transportation networks linking distant factories, and changing standards in telecommunications technology - fail Zambia as it is disassociated from alliances that previously supported its 'modernity'.

By foregrounding the actor-networks, an ANT study of development highlights hybridity instead of binaries (Latour, 1988b). To be sure, the complexity of 'development' does come through at times in the post-development literature (e.g. Escobar, 1995: 96), but elsewhere, the approach is overwhelmingly dichotomous, even critical of hybridization when located (e.g. Escobar, 1995: 46). The discomfort between post-development's structural assumptions of domination and its empirical findings of what might variously

\footnotetext{
${ }^{14}$ However, in his later work, Ferguson (2006, especially Ch. 1) does explicitly questions the accuracy of common approaches to 'the global'.

${ }^{15}$ Considering Comaroff and Comaroff (1991), who take an actor-oriented approach, Escobar (1995: 95) notes that 'hegemony is more unstable, vulnerable, and contested than previously thought'.
} 
be called localization (Escobar, 2009), bricolage (Comaroff \& Comaroff, 1991; de Certeau, 1984) or hybridization (Garcia Canclini, 1990) can be rectified through an actor-network approach that studies translation, keeps the social flat, and - as shown in the next section - distributes agency more broadly.

\section{Distributed Agency and the End of Mastery}

Latour is probably most (in)famous for an additional type of hybridity: controversially extending agency to nonhumans (e.g. Schaffer, 1991). ${ }^{16}$ Put simply, actor-network theory argues that because (a) action is mediated by nonhumans, and (b) all mediation involves a translation, agency must be understood as distributed (Latour, 1999a, 1994) Activity is always under-determined, meaning that the twists and turns it takes remain uncertain. Because 'local' interactions involve a confluence of previous and distant interactions that have been localized, how we are mediated and therefore translated is, at least in part, unclear; in other words, 'what is acting when "we" act' is uncertain (Latour, 2005: 45).

Acknowledging the unconventionality of this argument, Latour (1999a: 192) writes, 'Purposeful action and intentionality may not be the properties of objects, but they are not the properties of humans either. They are the properties of institutions, of apparatuses, of what Foucault calls dispotifs'. Therefore, 'responsibility for action must be shared among the various actants', so that the 'prime mover of an action becomes a new, distributed and nested series of practices whose sum may be possible to add up but only if we respect the mediating role of all the actants mobilized in a series' (ibid.: 182). Put simply, 'Boeing 747s do not fly, airlines fly' (ibid.: 193).

Although liable to introduce uncertainty at any time, nonhumans are also key to stabilizing society. For Latour, the presence of techniques, artefacts, and other nonhumans is central to the study of how power relations become sturdy. Compared to baboons, whose limited materiality requires the constant reassembling of their social existence (Latour, 1996b), Latour declares that 'technology is society made durable', meaning stability is largely achieved in human society through distributing and delegating to nonhumans (Latour, 1991b). As suggested above, 'in order to understand domination we have to turn away from an exclusive concern with social relations and weave them into a fabric that includes non-human actants' (ibid: 103). When technology can be stabilized enough to become 'black boxed' it is one of the chief ways that micro-actors can become macro: 'macro-actors are micro-actors seated on top of many (leaky) black boxes. They are neither larger, nor more complex than micro-actors' (Callon and Latour, 1981). In a classic paper on colonization, Law (1986: 253) offers this example of the importance of nonhumans: 'The Portuguese mariner, on a vessel with a cannon, was

\footnotetext{
${ }^{16}$ It is worth noting that many analysts who are uncomfortable imputing agency to entities such as roads or dams are comfortable extending causal powers to 'class' or 'capitalism'.
} 
indeed powerful. The same mariner, shipwrecked on a beach, was pathetically weak'. Similarly, 'development experts' can, indeed, wield great power, but only by building on networks that include many nonhumans.

While society is constructed, it is not socially constructed, because the borders between 'social' and 'technical' are too spurious to maintain. Mitchell's (2002) careful attention to technique in postcolonial Egypt shows the importance of studying both humans and nonhumans. In his telling, mosquitoes and the Aswan Dam are as worthy of consideration as Nasser, and as lively, too! The continual surprise that arises from contingencies in Egyptian history also indicates the limitations of 'mastery', either of humans by technology or vice versa (Latour, 1999c). For Latour, humans and nonhumans are not in a tug-of-war for control, but rather more activity by one enables more activity by the other (Latour, 1999a).

The distribution of agency amongst innumerably more entities, and the suspension of assumption of mastery - and its kinfolk domination, dependence, and liberation - is at odds with two approaches within post-development. The first approach has its legacy in critical theorists of technology like Heidegger (1977), Mumford (1967), and Ellul (1967) who - at the risk of oversimplifying - think technology is a dominating force. In the post-development version, epitomized by Alvares (1992a,b) and Ullrich (1992), science and technology are synonymous with Western domination. This approach is surely too simplistic (Tilley, 2011). While it is true that 'the West' has longer chains of action with greater numbers of nonhumans enrolled, there is nothing intrinsically Western about that (Latour, 1994). Examples abound of nonhumans being enrolled in contradiction to 'the West'; as Escobar (2009) relates, the local community in his fieldwork was able to enrol digital technologies into their efforts to resist perceived Westernization.

The second tendency is present in both Escobar (1995) and Ferguson (1994) and might be called the 'machinic' approach in deference to Ferguson's evocative use of Foucault (1979, 1980) and Deleuze (1988). Perceiving the difficulty of identifying sources of action in any clear, unilateral or direct manner, this approach does away with 'master practices', acknowledges 'unpredictable outcomes' (Ferguson, 1994: 276) and posits 'strategy without strategists' (Escobar, 1995: 232). This approach shares with Latour a recognition that the 'prime mover of an action [is a] distributed and nested series of practices' (1999a: 182). It agrees to dismiss the concept of $a$ master, but whereas the machinic approach replaces one master with none, Latour advocates multiplying agency innumerably.

The holistic approach ANT uses is attentive, then, to both the uncertainty of action, as well as how domination comes about and remains durable. Anthropological studies of development could very much benefit from it: after all, when genetically modified seeds, anthropogenic climate change, or mobile phones are increasingly relevant to the lives of 
marginalized populations, it would be quixotic to limit attention to humans alone. Latour, then, encourages an object-oriented development, both in study and practice. While objects have obviously always appeared in studies of development, they are typically only large-scale ones such as dams and tractors and, even then, relegated to subordinate roles. Object-oriented development would extend the material productivity much further, such as to the documents, photographs and even logos that constitute land reform practices (Hetherington, 2011; additionally, see Hull, 2012). In this sense, Rottenburg's (2009) ethnography of development aid is a model, carefully attending to the technologies of representation and calculation that consume so much development effort.

\section{COMPOSING DEVELOPMENT? GONTRIBUTIONS TO A LATOURIAN DEVELOPMENT THEORY}

For both proponents and critics of the post-development school, an early and pressing question is 'well, what should we do?' - an inquiry that although loaded with political assumptions seems to greet any critical development study (Ferguson, 1994: 279). As a predominantly negative project, post-development does not provide, in the words of Ferguson (1999: 250), 'an intellectual and cosmological framework for interpretation and explanation' nor a 'progressive political program for responding to... disastrous economic and social failures'.

The same question - and the 'will to improve' (Li, 2007) that drives it - will be directed at a development paradigm using ANT. The question of a positive programme for Latour has changed over time. In trying to develop a radically different social science, ANT, too, is 'mostly a negative' approach (Latour, 2005: 142). In the past, Latour has been outspoken about what he feels are academics' proclivity to seek political relevance instead of doing accurate empirical work. Political relevance is rare for scholarship, and critical attempts to influence politics are largely mistaken and haphazard: 'Social explanations have of late become too cheap, too automatic; they have outlived their expiration dates - and critical explanations even more so' (ibid.: 221).

Despite this, it is possible to draw a more positive agenda from Latour's work, especially as it has become more clearly articulated in recent years. This section seeks to draw out some of those arguments, suggestions, and pathways towards a Latourian development theory.

\section{From 'Matters of Fact' to 'Matters of Concern'}

The foundation for such a programme would be grounded in Latour's theory of modernity. For Latour, the core commitment of the post-Enlightenment era has been the nearly universally held belief that through the application of Science and Reason, humans 
are able to separate Nature from Society, Fact from Value, Object from Subject. This is what he refers to as 'the Modernist settlement' (Latour, 1991a):

In the past, our ancestors confused facts with values, the essences of things with the representations they had of things, harsh objective reality with the fantasies that they project onto reality... Tomorrow, the moderns are sure, the distinction will be sharper; we shall be able to pry the established facts more decisively away from their mantra of desires and human fantasies. (Latour, 2004: 188)

Moderns, then, are those who think this process is to our benefit, postmoderns are those who feel that Science and Reason are no longer succeeding, and anti-moderns are those who cast it all in a negative light. Yet, all three camps accept the premise of purification and separation of distinct realms (Latour, 1991a).

It was only through studying science in action that Latour and his colleagues were able to demonstrate that the premise is completely flawed: 'what happens in reality is exactly the opposite: the more we move on, the more entangled we become with a greater number of entities which cannot be neatly distinguished between what belongs to society and what belongs to the "natural order" of "matters of fact" (Latour, 2011c). Science is not a distinct realm from politics (cf. Bourdieu, 2004), technology is not unique from society (Bijker et al., 1987), and any glance at a newspaper article on a climate change negotiation or genetically modified crop protests confirms it (Latour, 1991a). Yet, most approaches assume there are 'matters of fact', objective and clearly delineated from society, culture and politics. A fact is a fact, no matter where it is in the world, insists the Modern, end of story, no debate possible. That this is empirically false led Latour (1991a) to explain that we have never been modern.

In contrast, Latour says the world is populated with 'matters of concern'. Where facts are risk-free and objective, matters of concern are not firmly substantiated, prone to unintended consequences, and deeply intertwined with particular situations (Latour, 2004, 2003b). The categorical shift that Latour advocates introduces ethical and political considerations to domains where they were previously excluded. It can be further extended through closely linked notions of 'care' (Puig de la Bellacasa, 2011), drawing attention to responsibility toward 'neglected things'.

In many ways, post-development works can be read as an effort to demonstrate that alleged matters of fact - poverty exists, development is good, progress is inevitable are, in reality, matters of concern, meaning they are worthy of questioning, deliberation, and purposeful alteration instead of passive acceptance. Both ANT and post-development emphasize that politics is not some sort of reserve, left over for when facts have been determined, but rather central and ongoing. But whereas Ferguson's (1994: 256) 
argument - that 'technical solutions to the sufferings of powerless and oppressed people...is the principle means through which the question of poverty is de-politicized in the world today' — offered a negative critique, Latour's points to a positive political program: 'if science and techniques are politics pursued by other means, then the only way to pursue democracy is to get inside science and techniques' (1988b: 22). This strong claim emphasizes the importance of not allowing expertise to prematurely close public debate (Callon et al., 2011) and aligns with Ziai's (2004: 1057) version of postdevelopment as a 'manifesto of radical democracy' that 'extends conflictuality to the area of development policy'.

An object-oriented development should not be confused with a justification for the technocentric approach to development that has been rightly, roundly and routinely criticized. Instead, it builds on the insights of ANT, especially that humans and nonhumans exist in actor-networks, or chains of translation, through which action is possible. Our mediated existence demands a social theory, including a theory of social change and development, which is sensitive to the heterogeneous actor-networks in which our existence is possible.

Even the most vocal and powerful voices for enhancing sociological and anthropological methods in development have recognized the importance of hybridity, attentive to both humans and nonhumans. Although Michael Cernea's (1985) rallying cry of 'putting people first' seems on its face to be to the exclusion of science and technology, he was actually deeply aware of their importance (even if he did subscribe to the modernist premise of two distinct spheres). Undoubtedly, he was frustrated with 'a virtually exclusive emphasis on physical infrastructure' (ibid.: 2) in development and argued that 'people are - and should be - the starting point, the center, and the end goal of each development intervention' (ibid.: xiv), but it is tempting to read him more as a Hegelian antithesis to the dominant 'technocratic and econocratic biases in development work,' (ibid.: xii) not their pure negation.

In fact, even within his work, synthesis is suggested. Cernea was committed to creating techniques for sociological development workers. He argued that sociologists should 'grasp the 'technical' criteria of a project, and that 'technical experts' must not 'remain ignorant of sociostructural and cultural dimensions' (ibid.: 35). In truth, Cernea wanted development workers and projects to be as hybrid as the world they seek to change. A Latourian approach to development would concur, noting that there is no neat split between 'social' and 'technical', and that there is certainly no zero-sum tug-of-war between them (or sociologists and economists, for that matter) Rather, 'the more nonhumans share existence with humans, the more humane a collective is' (Latour, 1999a), as long as we recognize and treat them as matters of concern. These assemblages of humans and technologies can create a more enabling and emancipatory world, akin to 
Corbridge's (1998: 144) point in his critique of post-development that 'science as method can be liberating where it is lit up by a healthy skepticism'.

\section{Progressive Composition of the Common World}

To meet the challenges posed by matters of concern, the typical approaches to politics (and development) are insufficient. Modernists delegate to science the task of sorting out facts (whether they were chemical or economic) and leave politics for negotiating the remaining values. For Latour, the appeal to 'facts' is both empirically mistaken and serves to short-circuit political due process. Instead, he has argued that 'nothing is beyond dispute' (2010: 478) and we must recognize the capacity (and responsibility) to actively negotiate and engage the world instead of surrendering to 'facts' that are liable to suddenly breakdown given their inherent uncertainty.

The overriding concern of his approach is to progressively 'compose the common world' (Latour, 2010). The term 'compose' is meant to emphasize agency while maintaining that the resulting composition is made of heterogeneous components. ${ }^{17}$ 'Compose' is also appropriate in this context because a composition can readily fail, something that is not well captured in the teleological approaches to modernization and development (Ferguson, 1999).

The goal is to compose a common world, because for Latour there exists a moral imperative to include entities currently outside the collective, such as an 'unemployed person, some teenager on a street in Djakarta, or perhaps a black hole, forgotten by everyone, at the edge of the universe' (Latour, 2004). Given the importance of science and technology to Latour's analysis, it should not be surprising that the role of scientists in stabilizing and including new entities, such as black holes or changing weather patterns, is central to his political theory. But his tenet of inclusion also extends to more traditional, human entities that are largely excluded from the chains of translations, the actornetworks, which would allow them to reach their goals. In his most recent book, Ferguson has similar concerns, emphasizing 'the continuing claims of Africans and others to full membership rights in a world society' (2006: 166, emphasis added) The well-meaning anthropological impulse to recognize multiple modernities (of which Africans are members) may actually obscure the desires of Africans to be included in 'conditions that they themselves regard as modern' (ibid.:167)

For Latour, one of the main ways to undertake this task of inclusion is through economics, which he broadly defines to include 'accounting systems and modeling

\footnotetext{
${ }^{17}$ To avoid the Modernist separation of society and nature, Latour proposes 'collective' as an encompassing term.
} 
scenarios, mathematicians, marketing specialists, and statisticians' (2004: 136). ${ }^{18}$ Economics is to be lauded for its ability to produce new compositions of heterogeneity through innovation, and the resulting shifts in interests and desires that allow things to be drawn together more closely. Underlying this ability of economics is the commensurability enabled through standardization and calculations. He argues that economics has 'amplified, for at least the last two centuries, not only the scale at which humans and nonhumans are connecting with one another in larger and larger assemblies, but also the intimacy with which such connections are made' (Latour, 2007a).

For critical development scholars, at the very least, this argument may seem woefully ignorant of the downsides of economic processes. Some may dismiss the premise altogether, pointing out that it is the very fact of inclusion in capitalist markets that makes people worse off (Frank and Gills, 1996; Wallerstein, 2004). To continue with the examples from the first half of this paper, Ferguson (1999: 242), following Neil Smith (1997), writes, 'Expulsion and abandonment (in Smith's terms), disconnection and abjection (in my own), occur within capitalism, not outside it'. Indeed, the criticism that ANT is biased towards Machiavellian or entrepreneurial victors, not their victims, is not new (Haraway, 1994; Mirowski and Nik-Khah, 2007; Star, 1991; Winner, 1993), but for a new range of ANT-inspired social studies of finance and economics, such carte blanche critique misses the plurality of economic practices. Following ANT co-creator Michel Callon, Latour (2004) has suggested a denaturalized approach to economics that avoids 'the belief that the economy defines the basis of the world', and seeks to salvage the 'virtues of the discipline of economics (in particular the formatting of ties)' (ibid.: 272) from its vices. Gibson-Graham (1996: 154) similarly emphasizes how essentialist and totalizing discourses about capitalism discourage 'the emergence of alternative visions and projections'.

For Gibson-Graham, the diversity of grassroots, community economic possibilities is heartening. Along these lines, Latour's willingness to entertain, even welcome, economic methods comes from his commitment to the uncertainty inherent in action that is mediated and translated. He opposes a view of interests as fixed and preordained. People should be considered open to dialogic interactions through which they may adapt new habits and practices (Akrich et al., 2002). ${ }^{19}$ The achievement of such composition relies

\footnotetext{
${ }^{18}$ Although economics (in addition to science, politics and morality) is given special attention in Latour's work, there is no reason to believe additional modes of inclusion should be neglected in the composition of a common world.

${ }^{19}$ This argument follows closely from the discomfort with theories of 'false consciousness' mentioned above: 'We don't want to rush into saying that actors may not know what they are doing, but that we, the social scientists, know that there exists a social force 'making them do' things unwittingly. Inventing a hidden social drive, an unconscious, [is not appropriate with ANT]. Not because actors know what they are doing and social scientists don't, but because both
} 
on what Stengers (2005: 193) calls 'diplomacy', or negotiations between individuals 'constrained by diverging attachments' who nonetheless are able to reach new agreements, albeit always incomplete, local and contingent. This ability to compromise is central to compositionism (Latour, 2010), but may sit uncomfortably with postdevelopment commitments and unease with capitalist production and exchange (see also Gibson-Graham, 1996: 126).

In practice, though, power differentials are of course stark. Latour includes two very important safeguards that aim to prevent insensitivity to this difference. The first of these is the qualification that compositionism applies only to 'topics that generate a public around them' (2007b). That is, politics should be issue-oriented, responsive to publics that emerge because the consequences of an action overflow routines or institutions. As Noortje Marres (2007) says, 'No issue, no politics'. 'Development', especially when preaching inclusion, often risks a quasi-missionary zeal that seeks new frontiers, often leading to new forms of 'inclusive exclusion' (Mitchell, 2007: 254) or dispossession (Elyachar, 2005), a practice this qualification is aimed at avoiding. Again, this echoes Ferguson's recent writing about how to avoid flawed teleology through listening to African desires for material improvements and symbolic status $(2006: 168,192)$, instead of accepting enduring difference.

The mandate of responsiveness only to issues that emerge must also be complemented with an additional safeguard. To avoid demanding compliance with alien practices and norms, compositionism emphasizes that compromise is a requirement for all. The ability of the excluded to define issues on their own terms should be enhanced (Latour, 2004). Recall that everything is negotiable: if the collective obtains some form of closure, it is only temporary (Latour, 2004; 2010). In his study of Pasteur, Latour documents how the world had to readjust agriculture, food processing and sanitation to include microbiology (1988a); on a broader scale, the progressive inclusion of China into the world economy requires redesigning trade networks, cultural flows and governance (Dahlman, 2011). ${ }^{20}$ Inclusion should not be taken to imply that there is a fixed collective into which outsiders must fit, nor should it ignore the role of politics in negotiating those momentary closures. In this way, a Latourian approach would echo Ziai's (2004) advocacy of radical democracy and Corbridge's (1998: 144) admonition that 'critical thinking and open political systems might be preconditions for the 'pluriverses' [post-developmental scholars] wish to celebrate'.

have to remain puzzled by the identity of the participants in any course of action if they want to assemble them again' (Latour, 2005: 47).

${ }^{20}$ In this regard, the efforts to identify 'Southern theory' (Connell, 2007; also, Comaroff and Comaroff, 2011), or even more fundamentally, different ontological orientations (Blaser, 2009a,b; de la Cadena, 2010), can be considered evidence of how the existing collective will require renegotiation. 


\section{Development as Attachment}

Unlike more common social-scientific uses of the term network, as grounded in technical or topological origins, in ANT, an actor is not only networked in some conditions, such as when they are connected to information technologies (e.g. Castells, 1996). Rather, for Latour, 'to be self-contained — that is to be an actor — and to be thoroughly dependent - that is to be a network - is to say twice the same thing' (2011a: 7). This relational concept of being is fundamental because it shifts the unit of analysis from the singular entity to the networks that support and enable it. While everything is ontologically networked, some things exist within chains of translation that allow for better ability to meet goals through mobilizing people and resources. Development would, in this approach, become the task of shaping the chains of translation that allow people to better meet their goals.

It would also apply to the practice of development. Mosse (2005) has documented this through his ethnography of aid policy and practice, showing that development projects 'do not fail, [but] are failed by wider networks of support and validation' (ibid.: xii). What matters, then, is to go about 'establishing, promoting and defending significant interventions' (ibid.) Similarly, Ferguson's (1994) classic critique of development's unit of analysis as a neatly bounded nation state showed how it misunderstood the networks of migration and remittances that structured life in rural Lesotho.

The attention to actor-networks challenges both mainstream and critical approaches to development. Mainstream approaches to development are overwhelmingly methodologically individualistic, from neoclassic economics to more philosophically oriented theories like Sen's (1999) capabilities approach. The concept of actor-network where the two terms are mutually constitutive - underlines the situated, material and relational aspects of being far more than is common in development. ${ }^{21}$ It also challenges the common conception of emancipation that defines attachment and entanglement as opposed to freedom and autonomy (Latour, 1999b, c). Instead, 'the stories of both emancipation and of attachment are a single story', with more attachment leading to more emancipation, thus shifting the question from attachment versus freedom to good versus bad attachment (2009a: 8).

This approach to attachment and autonomy also challenges the recidivist or anti-modern disposition of much critical development thinking. This propensity towards autarky arises from pessimism about the impact of 'outside' influence on 'undeveloped' regions. It has

${ }^{21}$ Selinger (2009) offers a more philosophically-inclined approach to Latour and development, suggesting similar points. 
roots both in Marxist scholarship on uneven development, but also finds sympathies in what might be called the 'anarchic' approach to post-development studies which is wary of the expansion of 'bureaucratic state power' (Ferguson, 1994; cf. Scott, 2010). A quite explicit example is Padel (2000: 289) who argues that 'remoteness tends to be the best insurance against poverty'. ${ }^{22}$

The post-development literature has struggled with how to balance this disposition with evidence that challenges it. For example, Escobar's (2009) sympathetic ethnography of Pacific Colombian activists resisting capitalist development argues that the thrust of modernity and development is at odds with indigenous, local forms of life. Modern epistemologies, techniques, and hierarchical structures are portrayed as imperial and destructive. However, Escobar finds that successfully meeting their goals - such as 'food autonomy' (ibid.: 147) - required the activists to 'further entangle themselves in the worlds from which they seek liberation' (ibid.; 227). Activists recognized this, building global networks of support, with one saying 'we can, and should, work within the structures of the state' (ibid.: 202). In his earlier book, Escobar (1995: 219) noted a similar finding: 'Paradoxically, however, the groups with a higher degree of economic autonomy and 'insertion' into the market have at times a better chance of successfully affirming their ways of life than those clinging to signs of identity, the social force of which has been greatly diminished by adverse economic conditions'.

Yet, the insight of an actor-network orientation shows that there is nothing paradoxical about it. Although romantics might pine for isolation, the reality is that poor people want to improve their lot (De Vries, 2007; Ferguson, 2006). Even when their desires are stated in terms of autonomy and maintaining their social, cultural or economic practices (as was the case with Escobar's activists), success requires mobilizing a wider and wider network. As Latour found years ago studying lab scientists, the more autonomy was wanted 'inside' the lab, the more the scientists had to engage 'outside' donors, reviewers and experts (Latour and Woolgar, 1979; Latour, 1987). Autonomy does not come from isolation, but rather from wider and wider networks. ${ }^{23}$ Freedom is not detachment, but rather its opposite. $^{24}$

\footnotetext{
${ }^{22}$ Within anthropology, of course, this relationship with 'noble savages' has a storied genealogy (e.g. Sahlins, 1974).

${ }^{23}$ Even the most extreme cases of autonomy confirm this: 'uncontacted tribes' in the Amazon region have not remained isolated by sheer local endeavour, but rather through a 'Sisyphean' effort made by the governments, scientists, media and more to maintain the isolation (Terborgh, 2012).

${ }^{24}$ Escobar (2009) notes that 'there are high costs of time and energy' in the activists' wider engagements. This is true. Some have commented that, perhaps, a more appropriate term for network would be 'work-nets'.
} 
The Modernist mistake of conceiving of 'growth and development without attachment and entanglement' (Latour, 2011b: 6) has similarly afflicted mainstream development thought. The post-development search for 'alternatives to development' also presumes a pure state, unbridled by attachment and entanglement. This is related to the aforementioned commitment to the concept of mastery that should be discarded in favour of focusing on 'the multitude of little choices contained with ties that differentiate... the good ties from the bad' (Latour, 1999c: 25). That is, emancipation 'does not mean 'freed from bonds' but well-attached' (Latour, 2005: 286). ${ }^{25}$ While bad forms of attachment certainly abound - from slavery to patriarchy - a Latourian development studies would take a stance of distinguishing between types attachment, not between attachment and autarky. For instance, the problem of contemporary debt peonage is not only the subservient relationship, but also the lack of attachments to alternative livelihood opportunities, support groups, legal protection, and the like.

This also has implications for the development concept of 'empowerment'. As Mosse (2005: 218) writes, 'people become 'empowered' not in themselves, but through relationships with outsiders'. Ironically, insisting on local autonomy delegitimizes forms of dependence that can improve people's lives. ${ }^{26}$ Development as influenced by Latour would, therefore, be focused on enhancing the ability of poor and marginalized people to enrol humans and nonhumans in networks that create the conditions for them to reach their goals. ${ }^{27}$ Amount, density, and length of network attachment are not to be condemned, but instead specificity to scrutinize, seeking to substitute bad attachments for better ones. ${ }^{28}$

If the goal for 'development', then, is to be considered enabling people to become attached in more and better ways so they can mobilize networks to their goals, the

\footnotetext{
${ }^{25}$ Doing away with mastery also does away with individualistic theories of action: 'actors don't have a strategy; they get their battle plans, contradictory ones, from other actors' (Latour, 1996a: $162)$ On this issue, framed as 'compliance', see Ferguson (1999: 111, 128)

${ }^{26}$ Recent work by Ferguson (2011) suggests similar lines of inquiry, seeking a 'left art of government'.

${ }^{27}$ Exploring the similarities and differences of this approach with the 'social capital' literature could be fruitful. In brief, the direction taken here differs in at least two ways: first, it is interested in materiality in a way that social capital does not emphasize. Secondly, empowerment and capital cannot be considered a reservoir on which someone can draw: 'Power is not something you may possess and hoard... When an actor simply has power nothing happens and $\mathrm{s} / \mathrm{he}$ is powerless; when, on the other hand, an actor exerts power it is others who perform the action' (Latour, 1986; also see Mitchell, 2002) Like power, social capital is a result, not a cause, of action. See Woolcock (1998) for a comprehensive approach to social capital, and Elyachar (2005) for a more critical analysis of its role in dispossession.

${ }^{28}$ This concern with 'the life support systems, the Umwelt that makes it possible' for actors to exist (Latour, 2009a: 8) may find parallels in some literature on poverty, such as on 'the precariat' (Standing, 2011).
} 
approaches and methods by which this should be done remain unanswered. Because the world is populated with 'matters of concern' instead of unalterable facts, issues do not have predetermined solutions. In considering how to frame purposeful action in this paradigm, through his engagement with the German philosopher Peter Sloterdijk, Latour has offered a specific conceptualization of 'design' as a speculative contribution. His formulation is grounded in the design of craftsmen, attentive to detail, especially with regard to 'meaning — be it symbolic, commercial or otherwise' (2009a: 4). The meaning attached to issues is important because a project never starts from scratch: 'to design is always to redesign' (ibid.: 5) This approach imbues a certain humility and modesty into an effort, embodying precaution and at odds with the expertise-driven approaches to development that so often assume society can be remade de novo (cf. Scott, 1999). As such, it tends to echo Riles's (2011: 228) appeal for 'a more modest and participatory' approach that creates 'not a new architecture but a new way of thinking through existing techniques for governing'. Finally, the concept of design immediately brings to the fore ethical issues, questions of good versus bad design.

\section{GONGLUSION}

As is not so well known, for Mary Shelley, the real crime of the Creator, Doctor Frankenstein, is not to have invented a horrible monster. The true abomination, after he had given life to an unnamed being through some combination of hubris and high technology, is to have abandoned the Creature to itself. (Latour, 2007a)

Latour employs the story of Frankenstein as a corrective for modernist approaches to technology and society. The issues that need to be negotiated to improve the lives of the world's neediest are not easily sifted into two camps, one called facts (economic, scientific, etc.) and another called values (cultural, social, etc.) They are 'imbroglios, mixing many more heterogeneous actors, at a greater and greater scale and at an ever tinier level of intimacy requiring even more detailed care' (Latour, 2007a: 6). Yet our approaches to 'development' — post and otherwise — too easily accept the modernist assumptions.

This article has argued that despite the instances of productive critique and more nuanced approaches, post-development's tendency to essentialize and dichotomize weakens its analytical utility. The actor-network approach of Bruno Latour offers systematic ways to maintain much of the strengths of post-development while avoiding those weaknesses. The concept of translation as part of a constructivist analysis and a commitment to keeping the social flat allows a Latour-inspired development studies to avoid over-generalizing about the influence of development interventions, and instead foregrounds the adaptations and alterations inherent in social change. This is complemented by the inclusion of nonhuman techniques and artefacts, many of which are essential to analysing the processes of social change. 
In addition to providing a corrective to the critique of development, this article has argued that actor-network theory provides suggestions for a positive agenda of action, even if it remains, admittedly, fragmentary. Even those who recognize the productivity of critiquing 'development' as a utopian ideology are uncomfortable retreating to inaction and nihilism. Development, of course, is politics pursued by other means, and a Latourinspired approach transforms this into a practice that focuses on matters of concern, the composition of a common world, and enhancing the ability of people to meet their needs through deploying networks of mobilization.

Frederick Cooper's (2005: 139) call for scholarly discussions of modernity and development to reflect nuance and historical grounding broadly resonates with the approach outlined here, especially his argument that 'The interconnection - and commensurability - of different parts of the world is not only a historical fact but a resource, for good, for bad, and for much that lies in between'. Yet, as ANT-inspired scholars know, what 'lies in between' brings analytical and practical difficulties. As Marilyn Strathern (1996) has shown, the question of 'cutting the network' is concomitant with ANT analysis, including the intersection with development advocated above. In practice, actor-networks will be truncated, but analytically that may be difficult to identify, or perhaps even unsatisfying. All analysis is bounded, but foregrounding those partitions, those cuts in the actor-networks, is especially important for development studies, which, as Cooper (2005) writes, must be especially considerate in its negotiations of particularity and universalism. ${ }^{29}$ No doubt a Latourian development studies will have other shortcomings and challenges - for example, can it ethically address the very real coercion and violence undertaken in the name of development? - but it certainly need not be the only approach.

Surveying development studies after post-development, Escobar (2006: 449) noted a 'lively climate for more eclectic and pragmatic approaches', some of which bear similarities to a Latourian approach (e.g. Arce and Long, 2000; Gardner and Lewis, 1996), though none use ANT systematically. Through its analysis of key postdevelopment texts, this article suggests that doing so would prove fruitful. However, it must be done reflexively, especially given the aforementioned critiques of ANT, as well as the possibility of reaching similar ends without some of the complexity of ANT (Vandenberghe, 2002). In the end, though, this analysis suggests that not only does ANT provide better means of analysis and vocabulary for the study of development, it also

\footnotetext{
${ }^{29}$ Ferguson (1985: 669) provides a thoughtful example of one such negotiation in his discussion of the Bovine Mystique: 'We must look not for bounded 'spheres' defined by historicist assumptions but for local densities of interconnexion [sic], minor clusters that are neither autonomous nor bounded, but which have, nonetheless, a certain coherence'.
} 
provides insight into how to meet the pressing challenges to which the development industry attends. 


\section{REFERENGES}

Akrich, M., M. Callon and B. Latour (2002) 'The Key to Success in Innovation, Part I: The Art of Interessement', International Fournal of Innovation Management (6)2: 187-206.

Alvares, G. (1992a) 'Science', in W. Sachs (ed.) The Development Dictionary: A Guide to Knowledge as Power, pp. 219-32. London: Zed Books.

Alvares, C. (1992b) Science, Development and Violence: The Revolt Against Modernity. Oxford: Oxford UP.

Ahorro, J. (2008) 'The Waves of Post-Development Theory and a Consideration of the Philippines'. University of Alberta. www.cpsa-acsp.ca/papers-2008/Ahorro.pdf

Arce, A. and N. Long (eds) (2000) Anthropology, Development and Modernities. London: Routledge.

Bijker, W., T. Hughes and T. Pinch (1987) The Social Construction of Technological Systems: New Directions in the Sociology and History of Technology. Cambridge, MA: MIT Press.

Blaser, M. (2009a) 'Political Ontology: Cultural Studies without "Cultures"?', Cultural Studies 23(56): $873-96$.

Blaser, M. (2009b) 'The Threat of the Yrmo: The Political Ontology of a Sustainable Hunting Program', American Anthropologist 111(1): 10-20.

Blok, A and T.E. Jensen (2011) Bruno Latour: Hybrid Thoughts in a Hybrid World. London: Routledge.

Bourdieu, P. (1977) Outline of a Theory of Practice. Cambridge: Cambridge UP.

Bourdieu, P. (2004) The Science of Science and Reflexivity. Chicago: University of Chicago Press.

Callon, M. and B. Latour (1981) 'Unscrewing the Big Leviathan; or How Actors Macrostructure Reality, and How Sociologists Help Them to Do So', in K. Knorr and A. Cicourel (eds) Advances in Social Theory and Methodology: Toward an Integration of Micro- and Macro-Sociologies, pp. 277-303. New York: Routledge \& Kegan Paul.

Callon, M. (1986) 'Some Elements of a Sociology of Translation: Domestication of the Scallops and the Fishermen of St Brieuc Bay', in J. Law (ed.) Power, Action and Belief: A New Sociology of Knowledge, pp. 196-233. London: Routledge \& Kegan Paul.

Callon, M. (1998) The Laws of the Markets. London: Blackwell Publishers.

Callon, M., Y. Millo and F. Muniesa (2007) Market Devices. London: Blackwell Publishers.

Callon, M., P. Lascoumes and Y. Barthe (2011) Acting in an Uncertain World: An Essay on Technical Democracy. Cambridge, MA: MIT Press.

Castells, M. (1996) The Rise of the Network Society. New York: John Wiley \& Sons.

Cernea, M. (ed) (1985) Putting People First: Sociological Variables in Rural Development. Washington, DC: World Bank and Oxford UP.

Comaroff J. and J. Comaroff (1991) Of Revelation and Revolution V.1: Christianity, Colonialism and Consciousness in South Africa. Chicago, IL: University of Chicago Press.

Comaroff, J. and J. Comaroff (2011) Theory from the South: Or, How Euro-America is Evolving Toward Africa. New York: Paradigm Publishers.

Connell, R. (2007) Southern Theory: Social Science and the Global Dynamics of Knowledge. London: Polity.

Cooper, F. (2005) Colonialism in Question: Theory, Knowledge, History. Berkeley, CA: University of California Press.

Corbridge, S. (1998) 'Beneath the Pavement Only Soil': The Poverty of Post-development', The Journal of Development Studies 34(6): 138-48.

Dahlman, C. (2011) The World Under Pressure: How China and India Are Influencing the Global Economy and Environment. Palo Alto, CA: Stanford UP.

Deleuze, G. (1988) Foucault. Minneapolis, MN: University of Minnesota Press. 
De Certeu, M. (1984) The Practice of Everyday Life. Berkeley, CA: University of California Press.

De la Cadena, M. (2010) 'Indigenous Cosmopolitics in the Andes: Conceptual Reflections beyond 'Politics', Cultural Anthropology 25(2): 334-70.

De Vries, P. (2007) 'Don't Compromise Your Desire for Development: A Lacanian/Deleuzian Rethinking of the Anti-Politics Machine', Third World Quarterly 28(1): 25-43.

Elder-Vass, D. (2008) 'Searching for Realism, Structure and Agency in Actor Network Theory', The British Fournal of Sociology 59(3): 455-73.

Ellul, J. (1967) The Technological Society. New York: Vintage Books.

Elyachar, J. (2005) Markets of Dispossession: NGOs, Economic Development, and the State in Cairo. Durham, NC: Duke UP.

Escobar, A. (1995) Encountering Development: The Making and Unmaking of Development. Princeton, NJ: Princeton UP.

Escobar, A. (2000) 'Beyond the Search for a Paradigm? Post-development and Beyond', Development 43(4): 11-14.

Escobar, A. (2006) 'Post-Development', in D.A. Clark (ed.) The Elgar Companion to Development Studies, pp. 447-451. Northhampton, MA: Edward Elgar Publishing.

Escobar, A. (2009) Territories of Difference: Place, Movements, Life, Redes. Durham, NC: Duke UP.

Esteva, G. and M.S. Prakash (1998) Grassroots Post-Modernism: Remaking the Soil of Cultures. London: Zed Books.

Ferguson, J. (1985) 'The Bovine Mystique: Power, Property and Livestock in Rural Lesotho', Man, New Series 20(4): 647-74.

Ferguson, J. (1994) The Anti-Politics Machine: 'Development', Depoliticization and Bureaucratic Power in Lesotho. Minneapolis: University of Minnesota Press.

Ferguson, J. (1999) Expectations of Modernity: Myths and Meanings of Urban Life on the Zambian Copperbelt. Oakland, CA: University of California Press.

Ferguson, J. (2006) Global Shadows: Africa in the Neoliberal World Order. Durham, NC: Duke UP.

Foucault, M. (1979) Discipline and Punish: The Birth of the Prison. New York: Vintage.

Foucault, M. (1980) The History of Sexuality: Volume One: An Introduction. New York: Vintage.

Frank, A.G. and B.K. Gills (eds) (1996) The World System: Five Hundred or Five Thousand Years. London: Routledge.

Garcia Canclini, N. (1990) Culturas hibridas. Estrategias para entrar y salir de la modernidad. Mexico City: Debolsillo.

Garfinkel, H. (1967) Studies in Ethnomethodology. New York: John Wiley \& Sons.

Gardner, K. and D. Lewis (1996) Anthropology, Development and the Post-Modern Critique. London: Pluto Press.

Gibson-Graham, J.K. (1996) The End of Capitalism (As We Knew It). Minneapolis, MN: University of Minnesota Press.

Gupta, A. and J. Ferguson (1997) Culture, Power, Place: Explorations in Critical Anthropology. Durham, NC: Duke UP.

Hale, G.R. (2009) 'Review of the book Encountering Development: Place, Movements, Life, 'Redes', by A. Escobar', Fournal of Latin American Studies (41)4: 826-29.

Haraway, D. (1994) 'A Game of Cat's Cradle: Science Studies, Feminist Theory, Cultural Studies', Configurations: A Fournal of Literature and Science 2(1): 59-71.

Harman, G. (2009) The Prince of Networks: Bruno Latour and Metaphysics. Melbourne: Re.Press. 
Heidegger, M. (1977) The Question Concerning Technology, and Other Essays. New York: Garland Publishers.

Hetherington, K. (2011) Guerilla Auditors: The Politics of Transparency in Neoliberal Paraguay. Durham, NC: Duke UP.

Hull, M. (2012) Government of Paper: The Materiality of Bureaucracy in Urban Pakistan. Oakland, CA: University of California Press.

Law, J. (1986) 'On the Methods of Long Distance Control: Vessels, Navigation, and the Portuguese Route to India', in J. Law (ed.) Power, Action and Belief: A New Sociology of Knowledge?, pp. 234-263 New York: Routledge \& Kegan Paul.

Latour, B. and S. Woolgar (1979) Laboratory Life: The Social Construction of Scientific Facts. Cambridge: Harvard UP.

Latour, B. (1986) 'The Powers of Association', in J. Law (ed.) Power, Action and Belief: A New Sociology of Knowledge?, pp. 264-280 New York: Routledge \& Kegan Paul. New York: Routledge \& Kegan Paul.

Latour, B. (1987) Science in Action: How to Follow Scientists and Engineers Through Society. Cambridge, MA: Harvard UP.

Latour, B. (1988a) The Pasteurization of France. Cambridge, MA: Harvard UP.

Latour, B. (1988b) 'The Prince for Machines as Well as for Machinations', in B. Elliot (ed.) Technology and Social Change, pp. 20-43. Edinburgh: Edinburgh UP.

Latour, B. (1991a) We Have Never Been Modern. Cambridge, MA: Harvard UP.

Latour, B. (1991b) 'Technology is Society Made Durable', in J. Law (ed.) A Sociology of Monsters: Essays on Power, Technology and Domination, pp. 103-32. New York: Routledge.

Latour, B. (1994) 'On Technical Mediation: Philosophy, Sociology, Genealogy', Common Knowledge (3)2: 29-64.

Latour, B. (1996a) Aramis, or the Love of Technology. Cambridge, MA: Harvard UP.

Latour, B. (1996b) 'On Interobjectivity', Mind, Culture \& Activity (3)4: 228-45.

Latour, B. (1996c) 'On Actor-Network Theory: A Few Clarifications Plus More than a Few Complications', Soziale Welt 47: 369-81.

Latour, B. (1999a) Pandora's Hope: Essays on the Reality of Science Studies. Cambridge, MA: Harvard UP.

Latour, B. (1999c) 'Factures/Fractures: From the Concept of Network to the Concept of Attachment', RES: Anthropology \& Aesthetics 36: 30-31.

Latour, B. (2003a) 'The Promises of Constructivism', in D. Ihde and E. Selinger (eds) Chasing Technoscience: Matrix for Materiality, pp. 27-46. Indianapolis, IN: Indiana UP.

Latour, B. (2003b) 'Why Has Critique Run Out of Steam? From Matters of Fact to Matters of Concern', Critical Inquiry (30)2: 225-48.

Latour, B. (2004) Politics of Nature: How to Bring the Sciences into Democracy. Cambridge, MA: Harvard UP.

Latour, B. (2005) Reassembling the Social: An Introduction to Actor-Network Theory. Oxford: Oxford UP.

Latour, B. (2007a) 'It's the Development, Stupid! Or, How Can We Modernize Modernization?' http://bruno-latour.fr

Latour, B. (2007b) 'Turning Around Politics - A Note on Gerard de Vries' Paper', Social Studies of Science 37(5): 811-20.

Latour, B. (2008) 'What's the Story?' Organizing as a Mode of Existence'. http://bruno-latour.fr 
Latour, B. (2009a) 'A Cautious Prometheus? A Few Steps Toward a Philosophy of Design (with Special Attention to Peter Sloterdijk)', in F. Hackne, J. Glynne, V. Minto (eds) Proceedings of the 2008 Annual International Conference of the Design History Society, pp. 2-10. Falmouth, UK : Universal Publishers.

Latour, B. (2010) 'An Attempt at a 'Compositionist Manifesto', New Literary History 41: 47 1-90.

Latour, B. (2011a) 'Networks, Societies, Spheres: Reflections of an Actor-Network Theorist', International fournal of Communications 5: 773-87.

Latour, B. (2011b) 'Politics of Nature: East and West Perspectives', Ethics and Global Politics (4)1: 71-80.

Latour, B. (2011c) 'Summary of the AiME Project - An Inquiry into the Modes of Existence'. www.bruno-latour.fr/node/328

Latour, B. (2013) An Inquiry into Modes of Existence: An Anthropology of the Moderns. Cambridge, MA: Harvard UP.

Law, J. (2004) 'And if the Global Were Small and Non-Coherent? Method, Complexity and the Baroque', Society and Space 22(1): 13-26.

Lewis, D. and D. Mosse (2006) Development Brokers and Translators: The Ethnography of Aid and Agencies. Sterling, VA: Kumarian Press.

Li, T. (2007) The Will to Improve: Governmentality, Development and the Practice of Politics. Durham, NC: Duke UP.

Marres, N. (2007) 'The Issues Deserve More Credit: Pragmatist Contributions to the Study of Public Involvement in Controversy', Social Studies of Science 37(5): 759-80.

Merton, R.K. (1968) Social Theory and Social Structure. New York: Free Press.

Mirowski, P. and E. Nik-Khah (2007) 'Markets Made Flesh: Performativity, and a Problem in Science Studies, Augmented with a Consideration of the FGG Auctions' in D. MacKenzie, F. Muniesa, and L. Siu (eds) Do Economists Make Markets? On the Performativity of Economics. Princeton, NJ: Princeton UP.

Mitchell, T. (2002) Rule of Experts: Egypt, Techno-Politics, Modernity. Oakland, CA: University of California Press.

Mitchell, T. (2007) 'The Properties of Markets' in D. MacKenzie, F. Muniesa, and L. Siu (eds) Do Economists Make Markets? On the Performativity of Economics. Princeton, NJ: Princeton UP.

Mitchell, T. (2009) 'Carbon Democracy', Economy E̊ Society 38(3): 399-432.

Mosse, D. (2005) Cultivating Development: An Ethnography of Aid Policy and Practice. London: Pluto Press.

Mumford, L. (1967) The Myth of the Machine. San Diego, CA: Harcourt.

Padel, F. (2000) The Sacrifice of Human Being: British Rule and the Konds of Orissa. Delhi: Oxford UP.

Pieterse, J.N. (2000) 'After Post-Development', Third World Quarterly (21)2: 175-91.

Puig de la Bellacasa, M. (2011) 'Matters of Care in Technoscience: Assembling Neglected Things', Social Studies of Science 41(1): 85-106.

Rahnema, M. and V. Bawtree (1997) The Post-Development Reader. London: Zed Books.

Riles, A. (2011) Collateral Knowledge: Legal Reasoning in the Global Financial Markets. Chicago, IL: University of Chicago Press.

Rottenburg, R. (2009) Far-Fetched Facts: A Parable of Development Aid. Cambridge, MA: MIT Press. Sachs, W. (ed.) (1992) The Development Dictionary: A Guide to Knowledge as Power. London: Zed Books. Sahlins, M. (1972) Stone Age Economics. Hawthorne, NY: Aldine de Gruyter. 
Schaffer, S. (1991) 'The Eighteenth Brumaire of Bruno Latour', Studies in History \& Philosophy of Science (22)1: 174-92.

Sen, A. (1999) Development as Freedom. Oxford: Oxford UP.

Selinger, E. (2009) 'Towards a Reflexive Framework for Development; Technology Transfer After the Empirical Turn', Synthese 168(3): 377-403.

Scott, J. (1999) Seeing Like a State: How Certain Schemes to Improve the Human Condition Have Failed. New Haven, CT: Yale UP.

Scott, J. (2010) The Art of Not Being Governed: An Anarchist History of Upland Southeast Asia. New Haven, CT: Yale UP.

Smith, N. (1997) 'The Satanic Geographies of Globalization: Uneven Development in the 1990s', Public Culture 10(1): 169-89

Standing, G. (2011) The Precariat: The Dangerous New Class. New York: Bloomsbury.

Star, S.L. (1991) 'Power, Technology and the Phenomenology of Conventions: On Being Allergic to Onions', in J. Law (ed.) A Sociology of Monsters: Essays on Power, Technology and Domination, pp. 26-56. London: Routledge.

Stengers, I. (2005) 'Introductory Notes on an Ecology of Practices', Cultural Studies Review 11(1): 183-196.

Strathern, M. (1996) 'Cutting the Network', The Journal of the Royal Anthropological Institute 2(3): 51735.

Terborgh, S. (2012) 'Out of Contact', New York Review of Books 5 April.

Tilly, H. (2012) Africa as a Living Laboratory: Empire, Development, and the Problem of Scientific Knoweledge, 1870-1950. Chicago, IL: University of Chicago Press.

Ullrich, O. (1992) 'Technology', in W. Sachs (ed.) The Development Dictionary: A Guide to Knowledge as Power, 275-87. London: Zed Books

Vandenberghe, F. (2002) 'Reconstructing Humants: A Humanist Critique of Actant-Network Theory', Theory, Culture, Society 19(5-6): 51-67.

Wallerstein, I. (2004) World-Systems Analysis: An Introduction. Durham, NC: Duke UP.

Winner, L. (1993) 'Upon Opening the Black Box and Finding it Empty: Social Constructivism and the Philosophy of Technology', Science, Technology \& Human Values 18(3): 362-78.

Woolcock, M. (1998) 'Social Capital and Economic Development: Toward a Theoretical Synthesis and Policy Framework', Theory and Society 27(2): 151-208.

Ziai, A. (2004) 'The Ambivalence of Post-development: between Reactionary Populism and Radical Democracy', Third World Quarterly 25(6): 1045-60.

\section{About the Author}

Kevin P. Donovan is a PhD student in the Program in Anthropology \& History at the University of Michigan. His research interests include critical development studies, surveillance studies, science \& technology studies, and African history. Contact: kevinpd@umich.edu | Tisch Hall Room 1029, 435 S. State St., Ann Arbor, MI 481091003. 